\title{
Why Start New Journal
}

\author{
Leonid Ionin* \\ Department of Economics, Higher School of Economics, Russia
}

Submission: June 01, 2018; Published: June 11, 2018

"Corresponding author: Leonid Ionin, Professor for department of economics, Higher School of Economics, Moscow, Russia, Tel: +7-985-9237829; Email: ioninlg@gmail.com

\section{Opinion}

Currently, there are two views on the nature and, accordingly, future of scientific journals. The first is regulatory the second is descriptive and realistic. According to the first, scientific journals perform a dual function - they promptly inform the scientific community about the latest results of science, and at the same time work as a mechanism for regulating and maintaining a high level of research. The article sent to a journal is usually subjected to expert examination (peer review) and enters into competition with other articles. The more authoritative the journal, the stricter the selection and higher the requirements for professional level. Thus, scientific journals serve as feedback channels through which the scientific community regulates (increases) the level of research in the area.

This is, in the most general terms, a generally accepted view of the role of scientific journals in the current era. It is this understanding that the vast majority of universities, research institutes and individual scholars are guided by. It is publications in scientific journals of a certain level that determine the success of a scientist, his scientific career, as well as the university's rating and, ultimately, his financial, ideological and other role in the world.

The second approach is based on the fact that the influence and role of scientific journals in modern science has been falling for a long time. This is due to the following circumstances. First, many experts have come to an understanding that data on publication and citation are not an exhaustive measure of scientific productivity. Almost all such indicators are subject to manipulation procedures; the modern scientific community has fully mastered these procedures. Thus, journal publications and the estimates based on them lose their original meaning ${ }^{1}$.

Secondly, the system of reviewing, periodicity of publications and the period of expectations of publication meet less and less modern requirements. As a rule, the review system is a "stencil", which can only get through standard articles; truly original contributions are often rejected. These are the costs of a "paradigmatic" approach. If we use the terms of Thomas Kuhn, "normal science", embodied in the structure of journal activities, almost closes the way to "abnormal" research, which only overcome the boundaries of the usual and established.

At the same time, the review procedure and plans of journal publications lead to the fact that the articles "hang" in the editorial office for years. The rapid obsolescence of the issues under study denies such long publication lags. Third, scientific journals are now falling into the trap of commercialization. Subscriptions to leading journals are expensive, and if a scientist does not have institutional access to published texts, he is forced to access the texts via the Internet. But there downloading one article (without a guarantee of its usefulness for the seeker of information) costs up to 50-70 dollars.

It is from the awareness of these difficulties and from the understandable desire to make knowledge available to all that the model of "open access" has emerged. According to this model, the reader does not have to pay for reading the article, the writer pays for publishing his article in the journal, and the journal accepts the articles of all comers with almost no quality control. But this has led to the emergence of a huge fraudulent industry of scientific publications. More about this is stated in the "Science" and elsewhere.

In this regard, a natural question may arise: why in such circumstances to start publishing a new journal?

This may seem strange, but it is in increasing the number of scientific journals from responsible publishers that the way to overcome the existing difficulties of the functioning of the science infrastructure may lie. There should be a lot of magazines even with the same subject and different compositions of editorial boards which implies a certain paradigmatic differences. It is this kind of "polycentric" science that allows to overcome the violence of the dominant paradigm, that is, in a certain sense, the violence of authoritative journals.

As for the commercialization of publishing activities, the situation is much more complicated. "Co modification" of 
everything in the world, including scientific knowledge, is an integral feature of our time. Of course, this does not coincide with the principles of freedom of knowledge, characteristic of the ideal "republic of scientists", formulated at the dawn of modernity. This contradiction is recognized by many scientists, and often very painful. Science is now clearly in the process of reconstructing its infrastructure bases, and in these conditions, every new start is a blessing.

Your next submission with Juniper Publishers
will reach you the below assets
- Quality Editorial service
- Swift Peer Review
- Reprints availability
- E-prints Service
- Manuscript Podcast for convenient understanding
- Global attainment for your research
- Manuscript accessibility in different formats
( Pdf, E-pub, Full Text, Audio)
- Unceasing customer service
Track the below URL for one-step submission
https://juniperpublishers.com/online-submission.php

